\title{
Metastases of squamous cell carcinoma of the head and neck show increased levels of nucleotide excision repair protein XPF in vivo that correlate with increased chemoresistance $e x$ vivo
}

\author{
BEATE KÖBERLE $^{1 *}$, CLAUDIA DITZ ${ }^{2 *}$, INGO KAUSCH ${ }^{3}$, BARBARA WOLLENBERG $^{2}$, \\ ROBERT L. FERRIS ${ }^{4}$ and ANDREAS E. ALBERS ${ }^{5}$
}

${ }^{1}$ Institute of Toxicology, University Medical Center, Mainz; Departments of ${ }^{2}$ Otorhinolaryngology, and ${ }^{3}$ Urology,
University of Schleswig-Holstein, Campus Lübeck, Germany; ${ }^{4}$ Departments of Otolaryngology and Immunology,
University of Pittsburgh and Cancer Institute, Pittsburgh, PA, USA; ${ }^{5}$ Department of Otorhinolaryngology
and Head and Neck Surgery, Charité-Universitätsmedizin, Berlin, Germany

Received November 24, 2009; Accepted January 8, 2010

DOI: 10.3892/ijo_00000612

\begin{abstract}
Nucleotide excision repair (NER) is a key node of resistance of tumour cells to the anticancer drug cisplatin. Testicular germ cell tumours (TGCT) show exquisite sensitivity towards cisplatin, and this has been connected to low levels of the NER proteins ERCC1 and XPF. Tumours of some patients with advanced head and neck squamous cell carcinoma (HNSCC) regress well under cisplatin chemotherapy but prediction of responsiveness is poor. Little is known about the levels of ERCC1-XPF in HNSCC tissues and cell lines. We investigated mRNA and protein levels of ERCC1 and XPF in 13 HNSCC cell lines and seven testis tumour cell lines and examined the correlation between levels of ERCC1 and XPF and cellular resistance towards cisplatin. No significant difference in mRNA expression of either ERCC1 or XPF in the HNSCC cell lines compared to the testis tumour cell lines was observed. Significantly higher XPF protein levels were found in HNSCC cell lines compared to testis tumour cell lines resulting in cellular cisplatin resistance. The data indicate a contribution of XPF protein for the cisplatin resistance observed in HNSCC cell lines. Subsequently, XPF and ERCC1 protein expression was investigated in cancer tissue of 34 patients. XPF levels were significantly higher in metastases of HNSCC patients than in primary cancer tissue. These findings indicate a contribution of XPF protein for the observed chemoresistance in some
\end{abstract}

Correspondence to: Dr Andreas E. Albers, Department of Otorhinolaryngology and Head and Neck Surgery, CharitéUniversitätsmedizin, Berlin, Germany

E-mail: andreas.albers@charite.de

${ }^{*}$ Contributed equally

Key words: testicular germ cell tumours, head and neck squamous cell carcinoma, cisplatin sensitivity, ERCC1-XPF endonuclease, predictive marker
HNSCC tissue. XPF protein may be a predictive marker for cisplatin responsiveness of metastases in HNSCC patients.

\section{Introduction}

Head and neck squamous cell carcinoma (HNSCC) account for approximately $5 \%$ of all cancers in the United States $(1,2)$. While early-stage HNSCC is treated relatively effectively, fewer than $40 \%$ of patients with advanced, metastatic disease are cured. The prognosis of the patient is also related to the site of the primary tumour and the presence of metastasis. The 5-year survival for all stages combined on the basis of Surveillance Epidemiology and End Results (SEER) data is about $60 \%$ (3). Despite significant improvements in surgery, radiation and chemotherapy, long-term survival rates in patients with advanced stage HNSCC have not significantly increased in the past 30 years (4-6). In contrast, over $80 \%$ of patients with advanced testicular germ cell tumours (TGCT) can be cured using cisplatin-based chemotherapy (7). A better understanding of why TGCT are sensitive to chemotherapeutic drugs may have implications for the improved treatment of other types of cancer such as HNSCC which is also frequently treated with platinum based chemotherapy.

Cell lines derived from TGCT retain their sensitivity towards DNA damaging drugs and radiation, reflecting the excellent clinical response $(8,9)$. The mechanisms underlying this sensitivity are not yet clear. We have found that TGCT cell lines are deficient in the repair of cisplatin-induced DNA damage $(10,11)$. To date the only known mechanism by which these lesions can be removed from the DNA is by nucleotide excision repair (NER). NER involves recognition of damage, opening of the DNA surrounding the lesion, incisions on both sides of the lesion, excision of a fragment containing the lesion followed by a DNA synthesis step to replace the excised fragment. The core incision reaction requires the proteins XPC-HR23B, TFIIH, XPA, RPA, ERCC1-XPF complex and XPG (12). We observed a low constitutive NER capacity in TGCT cell lines, and this deficiency was correlated with reduced levels of the NER 
proteins ERCC1-XPF and XPA $(13,14)$. These results indicate that the molecular basis for the curability of TGCT is related to low levels of some of the NER proteins. In contrast high ERCC1 expression was associated with resistance to platinum containing therapy in various human cancers. Several groups have investigated the influence of ERCC1 on resistance to anticancer chemotherapy (15-18). Collectively the data suggest that ERCC1 expression can be used as a marker for cellular or clinical resistance to cisplatin and its analogs. Whether this is the case for HNSCC is still unknown.

To establish a possible role of ERCC1-XPF complex as a marker for cisplatin resistance in HNSCC, mRNA and protein expression of the NER factors ERCC1 and XPF was investigated in seven HNSCC cell lines derived from primary tumours and in three autologous pairs of HNSCC cell lines derived from primary and corresponding metastatic HNSCC tumours. The expression of these genes was compared to that found in seven testis tumour cell lines. We correlated ERCC1-XPF expression with cellular resistance towards cisplatin. In addition ERCC1 and XPF protein levels were investigated in tissues derived from TGCT and HNSCC. A better understanding of the role of NER in platinum based cancer therapy might clarify the role of ERCC1 and XPF as molecular markers to help identify patients most likely to benefit from platinum based chemotherapeutic treatment.

\section{Materials and methods}

Cell culture. We utilized 7 testis tumour cell lines, 13 HNSCC cell lines and one ovarian carcinoma cell line. Characteristics of the cell lines are detailed in Table I.

The cells were grown as monolayers in $75 \mathrm{~cm}^{2}$ tissue culture flasks (Sarstedt, Nümbrecht) in DMEM medium supplemented with $10 \%$ heat-inactivated FCS, $1 \mathrm{mM}$ glutamine, $4.5 \mathrm{mg} / \mathrm{ml}$ glucose and $1 \mathrm{mM}$ sodium pyruvate in a humidified atmosphere of $5 \% \mathrm{CO}_{2}$ in air.

Tumour tissues. Tumour tissues were obtained from 10 patients with newly diagnosed testicular cancer and 24 patients with HNSCC in the respective outpatient clinics at the University Hospital of Lübeck, Germany. Metastatic tissue was available from 9 of the HNSCC patients for comparison with primary tumour tissue. Patient and tissue characteristics are detailed in Tables II and III. All patients signed an informed consent approved by the local IRB.

Cisplatin sensitivity measurements. Cytotoxicity against cisplatin was determined using the MTT assay (Sigma-Aldrich, Germany). One thousand cells were plated per well in a 96-well plate (Greiner, Frickenhausen, Germany). 5-10-wells were set up as untreated controls and 5-10 for each concentration of cisplatin. After overnight incubation, cells were treated with cisplatin (Bristol Myers Squibb, Munich, Germany) for $24 \mathrm{~h}$, washed twice with PBS and incubated in fresh medium for 3 days. After 3 days the MTT assay was performed according to the instructions of the manufacturer. The $\mathrm{IC}_{50}$ and $\mathrm{IC}_{90}$ values were determined from the survival curves using the software GraphPad Prism version 4.0 (GraphPad Software Inc., La Jolla, USA). The resistance factor (RF) $\left(\mathrm{IC}_{90}\right.$ of cell line under investigation/ $\mathrm{IC}_{90}$ of the cisplatin
Table I. Origin of cell lines.

\begin{tabular}{lllll}
\hline Cell line & Biopsy origin & Differentiation & Type & (Refs.) \\
\hline 2102 EP & Teratoma & & & $(29)$ \\
NCCIT & Testis & & & $(30)$ \\
NTERA & Testis & & & \\
833K & NSGCT & & M & $(31)$ \\
GCT27 & NSGCT & & P & $(19)$ \\
SuSa & NSGCT & & P & $(32)$ \\
TERA-I & NSGCT & & M & $(33)$ \\
SKOV-3 & Ovary & & P & $(34)$ \\
FaDu & Pharyngeal & & P & $(35)$ \\
CAL-27 & Tongue & & P & $(36)$ \\
ANT-1 & Pharynx & & P & \\
UT-SCC 65 & Pharynx & G2 & P & \\
UT-SCC 70 & Pharynx & G3 & P & \\
UT-SCC 89 & Pharynx & G2 & P & \\
UT-SCC 94 & Pharynx & G2 & P & \\
UT-SCC 16A & Tongue & G3 & P & $(37)$ \\
UT-SCC 16B & Tongue & G3 & M & $(37)$ \\
UT-SCC 42A & Larynx & G3 & P & $(37)$ \\
UT-SCC 42B & Larynx & G3 & M & $(37)$ \\
UT-SCC 60A & Tonsil & G1 & P & $(37)$ \\
UT-SCC 60B & Tonsil & G1 & M & $(37)$ \\
\hline
\end{tabular}

resistant ovary cell line SKOV-3) was determined for all testis and HNSCC cell lines. All cytotoxicity experiments were performed at least twice.

Total RNA extraction, cDNA synthesis and RT-PCR for analysis of gene expression. The expression of the mRNA of the ERCC1 and XPF genes was determined using the One-Step real-time RT-PCR method. Total RNA was isolated from cells grown to $70 \%$ confluency in 10-mm dishes. RNA isolation was performed using the RNeasy Mini Kit (Qiagen, Hilden, Germany). The procedure included a DNase treatment step. cDNA was prepared from the total RNA with the QuantiTect RT Mix (Qiagen). The reaction was carried out at $50^{\circ} \mathrm{C}$ for $20 \mathrm{~min}$ in a total volume of $20 \mu \mathrm{l}$ containing $0.05 \mu \mathrm{g}$ RNA, $10 \mu 1$ 2x QuantiTect Probe RT-PCR Master Mix, $1 \mu 1$ 20x Primer Mix, $1 \mu 1$ 20x QuantiProbe solution (both from Qiagen), $0.2 \mu 1$ QuantiTect RT Mix and RNAsefree water up to $20 \mu \mathrm{l}$. The reaction was terminated by incubation at $95^{\circ} \mathrm{C}$ for $15 \mathrm{~min}$. This step inactivated the reverse transcriptase and allowed activation of the HotStar Taq DNA-polymerase. The following real-time PCR consisted of 45 cycles of $95^{\circ} \mathrm{C}$ for $10 \mathrm{sec}, 56^{\circ} \mathrm{C}$ for $30 \mathrm{sec}$ and $76^{\circ} \mathrm{C}$ for $30 \mathrm{sec}$. Real-time PCR was terminated by incubation at $40^{\circ} \mathrm{C}$ for $30 \mathrm{sec}$. Each sample was measured in duplicate and each set of samples was independently generated 3 times. For quantitative detection of the PCR products the QuantiProbe principle of Qiagen was used. QuantiProbes are sequence specific probes that are 3'-labeled with FAM, a reporter fluorescent dye and 5'-labeled with a quencher molecule. 
Table II. Characteristics of patients with testicular cancer.

\begin{tabular}{|c|c|c|c|c|c|}
\hline Patient & Age, sex & Localization of the primary tumour & Histology & Therapy prior surgery & TNM stage \\
\hline 1 & $49, \mathrm{~m}$ & Testis & Seminoma & None & $\mathrm{pT}_{2} \mathrm{~N}_{3} \mathrm{M}_{0}$ \\
\hline 2 & $36, \mathrm{~m}$ & Testis & $\begin{array}{l}\text { Embryonic carcinoma and } \\
\text { seminoma }\end{array}$ & None & $\mathrm{pT}_{2} \mathrm{~N}_{0} \mathrm{M}_{0}$ \\
\hline 3 & $39, \mathrm{~m}$ & Testis & Seminoma & None & $\mathrm{pT}_{2} \mathrm{~N}_{0} \mathrm{M}_{0}$ \\
\hline 4 & $38, \mathrm{~m}$ & Testis & $\begin{array}{l}\text { Embryonic carcinoma and } \\
\text { seminoma }\end{array}$ & None & $\mathrm{pT}_{2} \mathrm{~N}_{2} \mathrm{M}_{0}$ \\
\hline 5 & $42, \mathrm{~m}$ & Testis & Seminoma & None & $\mathrm{pT}_{1} \mathrm{~N}_{0} \mathrm{M}_{0}$ \\
\hline 6 & $27, \mathrm{~m}$ & Testis & Non-seminoma & None & $\mathrm{pT}_{1} \mathrm{~N}_{0} \mathrm{M}_{0}$ \\
\hline 7 & $24, \mathrm{~m}$ & Testis & Seminoma, teratoma & None & $\mathrm{pT}_{1} \mathrm{~N}_{1} \mathrm{M}_{0}$ \\
\hline 8 & $42, \mathrm{~m}$ & Testis & Seminoma & None & $\mathrm{pT}_{1} \mathrm{~N}_{0} \mathrm{M}_{0}$ \\
\hline 9 & $21, \mathrm{~m}$ & Testis & Seminoma & None & $\mathrm{pT}_{1} \mathrm{~N}_{0} \mathrm{M}_{0}$ \\
\hline 10 & $43, \mathrm{~m}$ & Testis & Seminoma & None & $\mathrm{pT}_{2} \mathrm{~N}_{0} \mathrm{M}_{0}$ \\
\hline 11 & $58, \mathrm{f}$ & Tonsil & Squamous cell carcinoma & None & $\mathrm{pT}_{1} \mathrm{~N}_{0} \mathrm{M}_{0}$ \\
\hline 12 & $61, \mathrm{f}$ & Tonsil & Squamous cell carcinoma & None & $\mathrm{pT}_{2} \mathrm{~N}_{2 \mathrm{a}} \mathrm{M}_{0}$ \\
\hline
\end{tabular}

Table III. Characteristics of patients with HNSCC.

\begin{tabular}{|c|c|c|c|c|c|}
\hline Patient & Age, sex & Localization of the primary tumour & Histology & Therapy prior surgery & TNM stage \\
\hline 13 & $60, \mathrm{~m}$ & Oral cavity & Squamous cell carcinoma & Radiation & $\mathrm{pT}_{2} \mathrm{~N}_{0} \mathrm{M}_{0}$ \\
\hline 14 & $65, \mathrm{~m}$ & Larynx, hypopharynx & Squamous cell carcinoma & None & $\mathrm{pT}_{3} \mathrm{~N}_{2 \mathrm{~b}} \mathrm{M}_{0}$ \\
\hline 15 & $50, \mathrm{~m}$ & Oral cavity & Squamous cell carcinoma & Radiation & $\mathrm{pT}_{1} \mathrm{~N}_{0} \mathrm{M}_{0}$ \\
\hline 16 & $67, \mathrm{~m}$ & Larynx & Squamous cell carcinoma & None & $\mathrm{pT}_{4 \mathrm{a}} \mathrm{N}_{0} \mathrm{M}_{0}$ \\
\hline 17 & $47, \mathrm{~m}$ & Floor of mouth & Squamous cell carcinoma & None & $\mathrm{pT}_{2} \mathrm{~N}_{2 \mathrm{~b}} \mathrm{M}_{0}$ \\
\hline 18 & $68, \mathrm{f}$ & Floor of mouth & Squamous cell carcinoma & None & $\mathrm{pT}_{1} \mathrm{~N}_{0} \mathrm{M}_{0}$ \\
\hline 19 & $45, \mathrm{~m}$ & Floor of mouth & Squamous cell carcinoma & None & $\mathrm{pT}_{2} \mathrm{~N}_{2 \mathrm{~b}} \mathrm{M}_{0}$ \\
\hline 20 & $70, \mathrm{f}$ & Tonsil & Squamous cell carcinoma & None & $\mathrm{pT}_{3} \mathrm{~N}_{2 \mathrm{~b}} \mathrm{M}_{0}$ \\
\hline 21 & $56, \mathrm{~m}$ & Larynx, hypopharynx & Squamous cell carcinoma & None & $\mathrm{pT}_{2} \mathrm{~N}_{1} \mathrm{M}_{0}$ \\
\hline 22 & $75, \mathrm{~m}$ & Larynx & Squamous cell carcinoma & None & $\mathrm{pT}_{3} \mathrm{~N}_{0} \mathrm{M}_{0}$ \\
\hline 23 & $44, \mathrm{~m}$ & Larynx, hypopharynx & Squamous cell carcinoma & $\begin{array}{l}\text { Surgery, radiation, } \\
\text { cisplatin }\end{array}$ & $\mathrm{rpT}_{4 \mathrm{a}} \mathrm{N}_{0} \mathrm{M}_{0}$ \\
\hline 24 & $66, \mathrm{~m}$ & Tonsil & Squamous cell carcinoma & None & $\mathrm{pT}_{2} \mathrm{~N}_{2 \mathrm{~b}} \mathrm{M}_{0}$ \\
\hline 25 & $57, \mathrm{~m}$ & Hypopharynx & Squamous cell carcinoma & None & $\mathrm{pT}_{2} \mathrm{~N}_{2 \mathrm{a}} \mathrm{M}_{0}$ \\
\hline $26 \mathrm{a}$ & $50, \mathrm{~m}$ & Larynx & Squamous cell carcinoma & None & $\mathrm{pT}_{2} \mathrm{~N}_{2 \mathrm{~b}} \mathrm{M}_{0}$ \\
\hline $26 b$ & $50, \mathrm{~m}$ & Larynx & Lymph node metastasis & None & $\mathrm{pT}_{2} \mathrm{~N}_{2 \mathrm{~b}} \mathrm{M}_{0}$ \\
\hline $26 c$ & $50, \mathrm{~m}$ & Larynx & Lymph node metastasis & None & $\mathrm{pT}_{2} \mathrm{~N}_{2 \mathrm{~b}} \mathrm{M}_{0}$ \\
\hline $27 \mathrm{a}$ & $72, \mathrm{~m}$ & Hypopharynx & Squamous cell carcinoma & None & $\mathrm{pT}_{2} \mathrm{~N}_{1} \mathrm{M}_{0}$ \\
\hline $27 b$ & $72, \mathrm{~m}$ & Hypopharynx & Lymph node metastasis & None & $\mathrm{pT}_{2} \mathrm{~N}_{1} \mathrm{M}_{0}$ \\
\hline $28 \mathrm{a}$ & $70, \mathrm{~m}$ & Larynx & Squamous cell carcinoma & Surgery & $\mathrm{pT}_{3} \mathrm{~N}_{2 \mathrm{~b}} \mathrm{M}_{0}$ \\
\hline $28 b$ & $70, \mathrm{~m}$ & Larynx & Lymph node metastasis & None & $\mathrm{pT}_{3} \mathrm{~N}_{2 \mathrm{~b}} \mathrm{M}_{0}$ \\
\hline $28 \mathrm{c}$ & $70, \mathrm{~m}$ & Larynx & Lymph node metastasis & None & $\mathrm{pT}_{3} \mathrm{~N}_{2 \mathrm{~b}} \mathrm{M}_{0}$ \\
\hline $29 a$ & $43, \mathrm{~m}$ & Base of tongue & Squamous cell carcinoma & None & $\mathrm{pT}_{3} \mathrm{~N}_{1} \mathrm{M}_{0}$ \\
\hline $29 b$ & $43, \mathrm{~m}$ & Base of tongue & Lymph node metastasis & None & $\mathrm{pT}_{3} \mathrm{~N}_{1} \mathrm{M}_{0}$ \\
\hline $30 \mathrm{a}$ & $53, \mathrm{~m}$ & Tonsil & Squamous cell carcinoma & Surgery & $\mathrm{pT}_{4} \mathrm{~N}_{1} \mathrm{M}_{0}$ \\
\hline $30 b$ & $53, \mathrm{~m}$ & Tonsil & Lymph node metastasis & Surgery & $\mathrm{pT}_{4} \mathrm{~N}_{1} \mathrm{M}_{0}$ \\
\hline $31 \mathrm{a}$ & $51, \mathrm{~m}$ & Larynx & Squamous cell carcinoma & None & $\mathrm{pT}_{3} \mathrm{~N}_{1} \mathrm{M}_{0}$ \\
\hline $31 b$ & $51, \mathrm{~m}$ & Larynx & Lymph node metastasis & None & $\mathrm{pT}_{3} \mathrm{~N}_{1} \mathrm{M}_{0}$ \\
\hline $32 \mathrm{a}$ & $57, \mathrm{~m}$ & Hypopharynx & Squamous cell carcinoma & None & $\mathrm{pT}_{2} \mathrm{~N}_{1} \mathrm{M}_{0}$ \\
\hline $32 b$ & $57, \mathrm{~m}$ & Hypopharynx & Lymph node metastasis & None & $\mathrm{pT}_{2} \mathrm{~N}_{1} \mathrm{M}_{0}$ \\
\hline $33 \mathrm{a}$ & $68, \mathrm{~m}$ & Hypopharynx & Squamous cell carcinoma & None & $\mathrm{pT}_{2} \mathrm{~N}_{2 \mathrm{~b}} \mathrm{M}_{0}$ \\
\hline $33 b$ & $68, \mathrm{~m}$ & Hypopharynx & Lymph node metastasis & None & $\mathrm{pT}_{2} \mathrm{~N}_{2 \mathrm{~b}} \mathrm{M}_{0}$ \\
\hline $34 \mathrm{a}$ & $62, \mathrm{~m}$ & Larynx & Squamous cell carcinoma & None & $\mathrm{pT}_{4 \mathrm{a}} \mathrm{N}_{2 \mathrm{~b}} \mathrm{M}_{0}$ \\
\hline $34 b$ & $62, \mathrm{~m}$ & Larynx & Lymph node metastasis & None & $\mathrm{pT}_{4 \mathrm{a}} \mathrm{N}_{2 \mathrm{~b}} \mathrm{M}_{0}$ \\
\hline
\end{tabular}


Table IV. Oligonucleotide primers and probes used in real-time PCR.

\begin{tabular}{llll}
\hline Name & \multicolumn{1}{c}{ Sequence } & $\mathrm{T}_{\mathrm{m}}$ & Position (5'-3') \\
\hline ERCC1 & F: CTGATGGAGAAGCTAGAG & 60.4 & $667-684$ \\
& R: TGACTGTCCGTTTTGTTG & 64.2 & $752-735$ \\
& Q: TCTGACCACCGTGAAGT & 66.9 & $714-730$ \\
XPF & F: CTTTGATACTGGTTTTTG & 60.2 & $510-527$ \\
& R: GAGTTTACTGCTACATGGA & 64.7 & $605-587$ \\
& Q: GGAAAGAGTGATGAGAA & 65.2 & $534-550$ \\
HPRT & Qiagen no. 241027 & & \\
\hline
\end{tabular}

F, forward primer; R, reverse primer; Q, QuantiProbe; $\mathrm{T}_{\mathrm{m}}$, melting point in ${ }^{\circ} \mathrm{C}$.

Primers and probes for ERCC1 and XPF were designed with the QuantiProbe Design Software (Qiagen). The sequences of the real-time PCR primers and probes used are shown in Table IV. The primers and probe for the endogenous control gene HPRT were purchased from Qiagen, the reaction conditions were as recommended by the manufacturers. The real-time PCR assays were performed in a LightCycler ${ }^{\mathrm{TM}}$ (Roche Diagnostics, Mannheim, Germany). LightCycler Software Version 3.5.3 was used to calculate a threshold cycle $(\mathrm{Ct})$ value from the amplification plots for each reaction. The comparative $\mathrm{Ct}$ method was used for relative quantification of gene expression. Target gene expression was normalized to the endogenous control gene HPRT to correct for differences in cDNA quantity between samples.

Immunoblotting. Protein extracts from cell cultures were prepared by lysing cells grown to $80 \%$ confluency in $10-\mathrm{mm}$ dishes in $600 \mu 1$ of RIPA buffer (1\% Igepal CA-630, $0.5 \%$ Na-Deoxycholate, $0.1 \%$ SDS) supplemented with protease inhibitors (for $1 \mathrm{ml}$ RIPA buffer $30 \mu \mathrm{l}$ of $10 \%$ aprotinin, $10 \mu \mathrm{l}$ of each $10 \mathrm{mg} / \mathrm{ml} \mathrm{PMSF}$ and $10 \mathrm{mg} / \mathrm{ml} \mathrm{Na-orthovanadate).}$ To prepare protein extracts of the tumour tissues, 100-150 $\mu \mathrm{g}$ of tissue were homogenized in a tissue lyser (Qiagen) by applying $25 \mathrm{~Hz}$ twice for $150 \mathrm{sec}$ and $500 \mu \mathrm{l}$ RIPA buffer was added to the homogenized tissue. The cells were disrupted by pulling the cell suspension 5-10 times into a syringe with a 21-gauge needle. The lysate was incubated for 30-60 min on ice, centrifuged at $10,000 \mathrm{x}$ for $10 \mathrm{~min}$ at $4^{\circ} \mathrm{C}$ and the supernatant was recovered. Protein concentration was determined by the Bradford method. Protein (30 or $60 \mathrm{mg}$ ) was separated by electrophoresis on SDS $10 \%$ polyacrylamide gels. Proteins were transferred to nitrocellulose membranes and blotted in 3\% milk, PBS-Tween. Primary and secondary antibodies were as follows: ERCC $1,1 \mu \mathrm{g} / \mu \mathrm{l}$ of MAb 3F169; XPF, $1 \mu \mathrm{g} / \mu 1$ of MAb 3F98 (Biomol, Hamburg, Germany), B-actin. $1 \mu \mathrm{g} / \mu 1$ of monoclonal $\mathrm{Ab}$ (Abcam, Cambridge, USA); goat anti-mouse IgG $1 \mu \mathrm{g} / \mu \mathrm{l}$ (Bio-Rad, Munich, Germany). Proteins were visualized using the alkaline phosphatase conjugate substrate kit (Bio-Rad). Quantification of the protein bands was performed using the imaging system gel-Dok XR (Bio-Rad). Protein expression was normalized to $B$-actin protein.
Statistical analysis. The Wilcoxon Matched Pairs Test was used to compare mRNA levels of XPF and ERCC1 in HNSCC cell lines and testis tumour cell lines. Protein expression levels of XPF and ERCC1 between the groups of HNSSC primary tumours, HNSCC metastasis and TGT were compared with the Mann-Whitney-U test.

\section{Results}

HNSCC cell lines are more resistant towards cisplatin than testis tumour cell lines. Cisplatin sensitivity was determined in HNSCC cell lines versus testis tumour cell lines. Seven established HNSCC cell lines derived from primary tumours, three pairs of HNSCC cell lines derived from primary tumour and corresponding metastatic tumours, and seven testis tumour cell lines were treated with a range of concentrations of cisplatin for $24 \mathrm{~h}$. The survival curves are shown in Fig. 1, the $\mathrm{IC}_{50}$ and $\mathrm{IC}_{90}$ values which were calculated from the survival curves are summarized in Table V. All of the HNSCC cell lines showed considerable resistance towards cisplatin, with $\mathrm{IC}_{50}$ values ranging from 1.2 to $5.5 \mu \mathrm{M}$ and $\mathrm{IC}_{90}$ values between 13 and $32 \mu \mathrm{M}$ (Fig. 1A and Table V). In contrast, six out of seven testis tumour cell lines were extremely sensitive towards cisplatin, with $\mathrm{IC}_{50}$ values $<1 \mu \mathrm{M}$ (Fig. 1B and Table V). This is in agreement with published data on the hypersensitivity of testis tumour cell lines towards DNA damaging drugs (19).

The survival curves after cisplatin treatment in the three pairs of cell lines derived from primary HNSCC tumours and corresponding lymph node metastasis are shown in Fig. 1C. There was some variation in the cisplatin sensitivity within the paired cell lines with pair UT-SCC 60 being extremely sensitive and pair UT-SCC 16 showing the highest cisplatin resistance of all cell lines. Cell lines UT-SCC 16A and B were derived from a patient who underwent radiation therapy before surgery. Radiation might have resulted in the selection of resistant tumour cells explaining the extreme cisplatin resistance observed in this cell pair. Comparing the RF values only a slight increase in cisplatin resistance was observed in the metastatic cell line compared to the corresponding primary tumour cell line (Table V). Altogether, our data revealed that HNSCC cell lines are resistant to cisplatin 
A

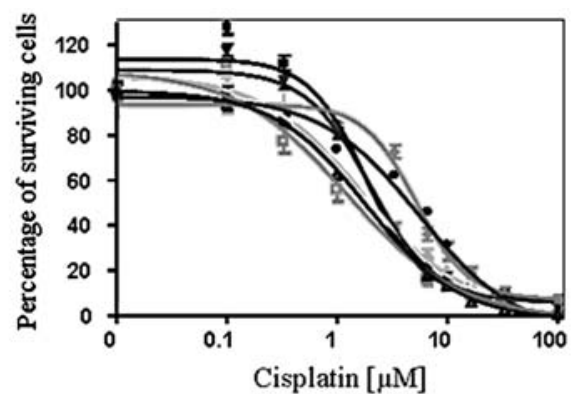

- ANT-1

Cal-27

- FaDu

- UT-SCC 65

- UT-SCC70

- UT-SCC 89

- UT-SCC 94

B

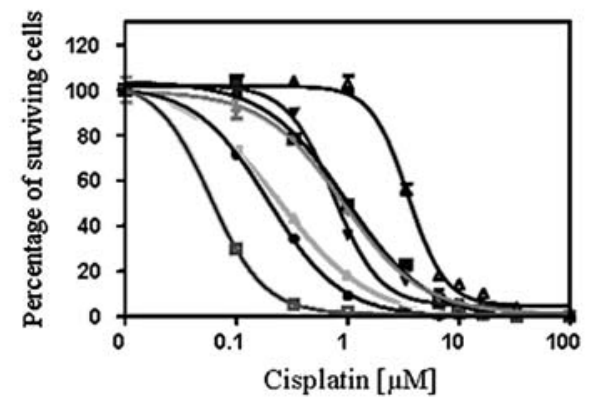

- $2102 \mathrm{EP}$

4 $833 \mathrm{~K}$

- GCT-27

- SuSa

- NCCIT

a NTERA

- tera

$\mathrm{C}$

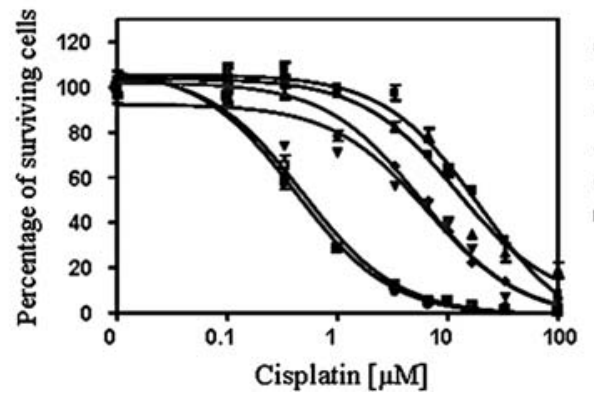

- UT-SCC 16 A

- UT-SCC 16 B

- UT-SCC 42 A

- UT-SCC 42 B

- UT-SCC 60 A

- UT-SCC $60 \mathrm{~B}$

Figure 1. Cell survival curves of 7 HNSCC cell lines (A), 7 testis tumour cell lines (B), and 3 paired cell lines derived from primary HNSCC tumours and corresponding lymph node metastasis (C) after exposure to increasing concentrations of cisplatin for $24 \mathrm{~h}$. The MTT assay was performed 3 days after cisplatin treatment. The plot shows mean values and the standard deviation of 5-10 experiments.

comparable to cell lines derived from other types of cancer such as bladder, ovary and prostate $(9,14)$.

$X P F$ and ERCC1 mRNA levels are comparable in HNSCC cell lines and testis tumour cell lines. ERCC1 and XPF mRNA expression in the cell lines was measured using quantitative RT PCR. We saw considerable variability in expression of ERCC1 and XPF mRNA among the cell lines tested. In the HNSCC cell lines ERCC1 mRNA levels are slightly higher than that of XPF mRNA (Fig. 2A), while in testis tumour cell lines XPF mRNA was present at a level higher than ERCC1 mRNA levels (Fig. 2B). Statistical analysis revealed no significant differences between testis tumour cell lines and HNSCC cell lines regarding ERCC1 and XPF mRNA expression. Similar observations have been reported for the comparison of testis tumour cell lines with cell lines derived from bladder, prostate, kidney and colon cancer cell lines. No difference in expression levels of ERCC1 and XPF mRNA has been observed among the cancer cell lines (20). Statistical analysis of our data revealed in addition that neither testis tumour cell lines nor HNSCC cell lines
Table V. $\mathrm{IC}_{50}$ and $\mathrm{IC}_{90}$ determined from the survival curves of Fig. 1.

\begin{tabular}{lrrr}
\hline Cell line & $\mathrm{IC}_{50}(\mu \mathrm{M})$ & $\mathrm{IC}_{90}(\mu \mathrm{M})$ & $\mathrm{RF}^{\mathrm{a}}$ \\
\hline 2102 EP & 0.98 & 5.82 & 0.38 \\
$833 \mathrm{~K}$ & 0.24 & 1.8 & 0.12 \\
GCT27 & 0.75 & 2.77 & 0.18 \\
SuSa & 0.90 & 5.82 & 0.38 \\
NCCIT & 0.20 & 0.97 & 0.06 \\
NTERA & 0.06 & 0.21 & 0.01 \\
Tera & 3.51 & 10.16 & 0.66 \\
ANT-1 & 1.84 & 17.71 & 1.16 \\
Cal-27 & 1.73 & 21.32 & 1.39 \\
FaDu & 2.03 & 16.67 & 1.09 \\
UT-SSC 65 & 5.24 & 32.87 & 2.15 \\
UT-SSC 70 & 5.58 & 27.31 & 1.78 \\
UT-SSC 89 & 1.25 & 13.83 & 0.90 \\
UT-SSC 94 & 1.86 & 13.00 & 0.85 \\
UT-SSC 16A & 19.38 & 88.37 & 5.78 \\
UT-SSC 16B & 12.09 & 100.00 & 6.54 \\
UT-SSC 42A & 6.58 & 42.09 & 2.75 \\
UT-SSC 42B & 5.75 & 44.77 & 2.93 \\
UT-SSC 60A & 0.41 & 2.61 & 0.17 \\
UT-SSC 60B & 0.48 & 3.15 & 0.21 \\
\hline
\end{tabular}

${ }^{a} \mathrm{RF}$, resistance factor: $\mathrm{IC}_{90}$ of cell line under investigation/ $/ \mathrm{IC}_{90}$ of SKOV-3.

showed a significant correlation between cisplatin resistance and expression of ERCC1 mRNA or XPF mRNA.

$X P F$ protein expression is significantly higher in HNSCC cell lines than in testis tumour cell lines. After observing similar expression of NER genes at the mRNA level, we wanted to know whether protein levels were also similar. Immunoblotting was performed to investigate the expression of the ERCC1 and XPF proteins in the 20 cell lines. The expression of $\beta$-actin was investigated as control protein. To determine the relative expression factor, the expression of ERCC 1 and XPF was normalized to $B$-actin expression. Examples of primary data are shown in Fig. 3A. Statistical analysis was performed to analyze whether HNSCC cell lines differed as a group from testis tumour cell lines (Fig. 3B). There was a significantly higher expression of XPF protein in HNSCC cell lines compared to testis tumour cell lines, the expression of ERCC1 was slightly higher. Regarding protein expression the HNSCC cell lines are comparable to cell lines derived from bladder, breast, prostate, lung cancer which all showed higher levels of ERCC1 and XPF protein compared to testis tumour cell lines (14). To check whether the levels of the NER proteins are one of the mechanisms underlying the sensitivity/resistance towards cisplatin we investigated the 
A
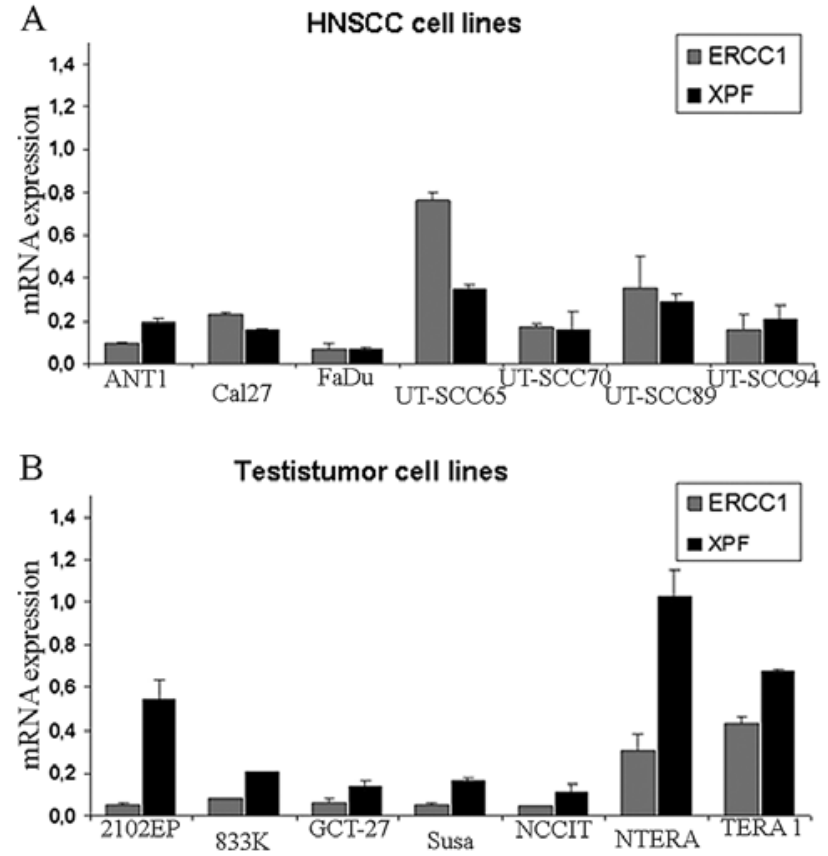

$\mathrm{C}$

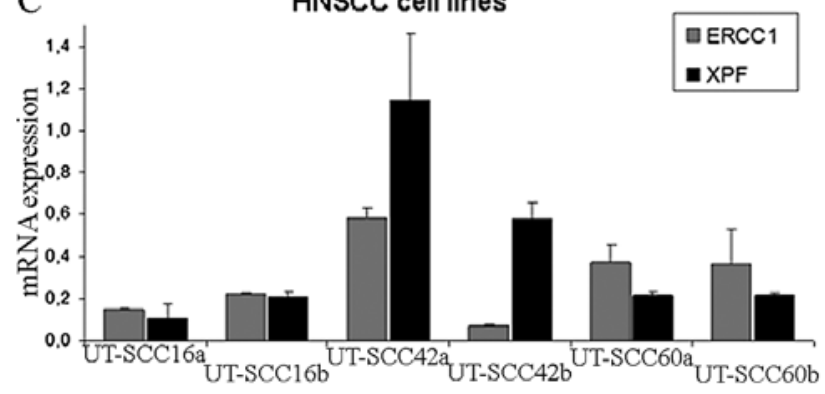

Figure 2. Expression of XPF and ERCC1 mRNA in 7 HNSCC cell lines (A), 7 testis tumour cell lines (B), and 3 paired cell lines derived from primary HNSCC tumours and corresponding lymph node metastasis (C). mRNA expression was determined using real-time RT-PCR. The mean values and standard deviation were calculated from $n=7$ experiments for testis tumours and $n=13$ experiments for HSCC lines.

correlation between expression levels and $\mathrm{IC}_{90}$ values. For $\mathrm{XPF}$ we found a significant correlation between protein expression and $\mathrm{IC}_{90}$ value $(\mathrm{p}<0.05)$.

$X P F$ protein expression is significantly higher in HNSCC metastases than in primary tumour tissue. Using immunoblotting we investigated the expression of ERCC1 and XPF proteins in cancer tissue derived from 24 patients with primary head and neck carcinoma. For 9 of the patients paired primary and metastasis tissue was compared. In addition as a reference for cisplatin-sensitive tissue we investigated ERCC1 and XPF levels in 10 testis tumour tissues. The expression levels were normalized to $B$-actin protein. We found a low expression of ERCC1 in both head and neck and testis tumour tissue (Fig. 4). No difference in ERCC1 expression levels has been found in primary versus metastasis tissue of head and neck cancer. Regarding XPF we found similar expression levels in head and neck primary tissue and testis tumour tissue. However, there was a significantly higher expression of XPF protein in metastatic compared to primary HNSCC (Fig. 4).

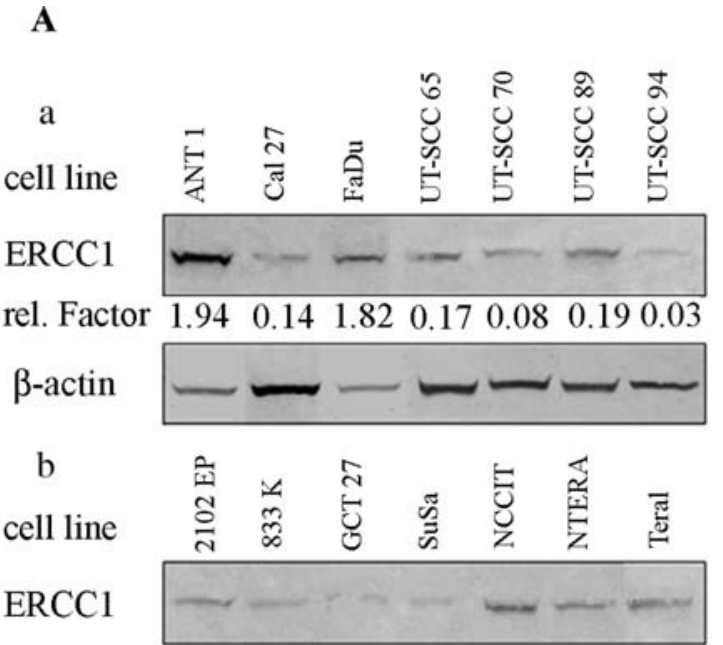

rel. Factor $0.28 \quad 0.17 \quad 0.04 \quad 0.040 .48 \quad 0.11 \quad 0.14$
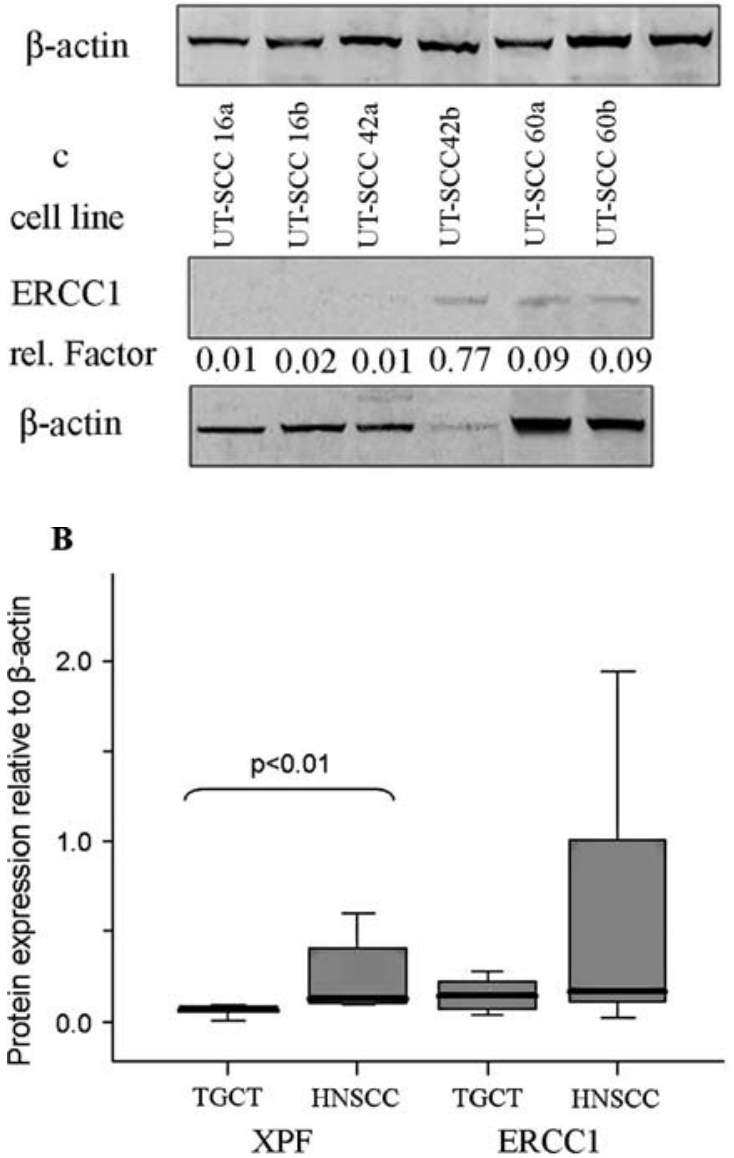

Figure 3. Examples of expression of ERCC1 protein (A) and statistical analysis of the expression of ERCC1 and XPF protein relative to $B$-actin (B) in HNSCC cells, testis tumour cells and paired cell lines derived from primary HNSCC tumours and corresponding lymph node metastasis. Protein levels were determined using immunoblotting. A statistical difference was found for the XPF expression of HNSCC versus TGCT. The ERCC1 expression reached no statstical difference.

\section{Discussion}

Every year about 500,000 cases of HNSCC are reported worldwide. Early-stage HNSCC disease is treated relatively well. However, $60 \%$ of patients present with advanced disease and fewer than $30 \%$ of these patients are cured. Management of advanced HNSCC consists of surgery, radiation and chemo- 


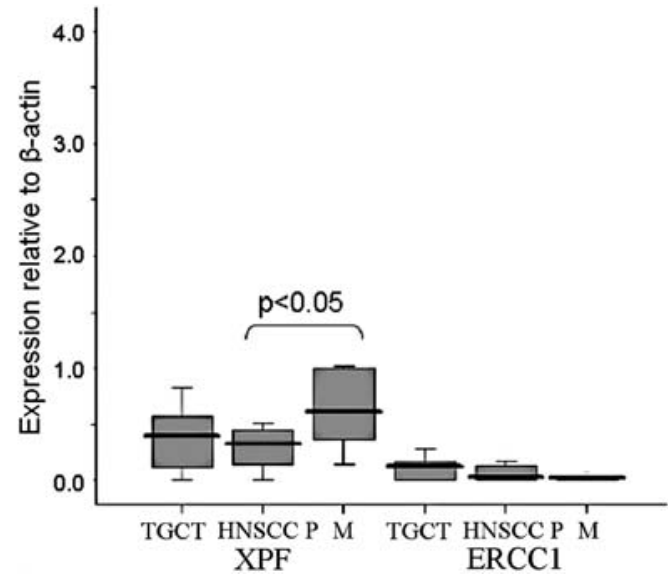

Figure 4. Expression of XPF and ERCC1 protein relative to ß-actin in tissue from 10 testicular cancer and 24 HNSCC primary and 10 metastatic tissue samples. Metastases express significantly higher levels of XPF then the primary tumours. Protein levels were determined using immunoblotting.

therapy with cisplatin being of particular importance. Clinical observation revealed that HNSCC metastatic tumours show higher resistance towards cisplatin compared to the primary tumour. However, this observation could not be confirmed in vitro using cancer cell lines. In three pairs of HNSCC cell lines derived from primary and corresponding metastatic HNSCC tumours only a small increase in resistance was seen when comparing the metastatic cell line with the respective primary tumour cell line. These findings reveal the importance of using patients' cancer tissue directly in addition to cell lines to elucidate the mechanisms underlying chemotherapeutic resistance.

Comparing cancer tissue no difference in ERCC1 and XPF levels was observed in testis tumour tissue versus HNSCC tissue. However, when comparing metastasis tissue from HNSCC with primary tissue of this tumour type we found a significantly higher expression of XPF protein in the metastasis tissue. The observed increase in XPF levels in metastatic tissue could contribute to the higher cisplatin resistance in metastatic HNSCC tissue compared to primary tumour.

Comparing cell lines derived from cisplatin sensitive testis tumours with cell lines derived from HNSCC we found that in HNSCC cell lines the XPF protein plays an important role for cellular resistance towards cisplatin. XPF associates with the ERCC1 protein to form a structure-specific endonuclease that functions in NER (22). The ERCC1-XPF nuclease catalyzes incision on the 5'-side of the DNA damage through an intrinsic activity of XPF. Mammalian cells with inactivating mutations in either the XPF or ERCC1 gene manifest impaired NER and consequently increased sensitivity towards DNA damaging drugs $(23,24)$. On the other hand in a number of studies the ERCC1 increase was linked to increased cellular resistance $(25,26)$. In clinical studies high levels of ERCC1 mRNA or protein in tumour tissue was often correlated with poor response towards cisplatin-based chemotherapy (15-18). In a recent study investigating ERCC1 expression as a predictive marker for tumour response and cancer survival in HNSCC patients it was reported that ERCC1 expression level negatively contributes to the clinical outcome (27). These data however have to be interpreted very carefully as the authors performed the study with an antibody against ERCC1 which recognizes an unknown antigen in addition to ERCC1 and is therefore reported to be unsuitable for immunostaining of human cells (28). In our studies we found a slightly higher level of ERCC1 in HNSCC cell lines compared to testis tumour cell lines which together with the significantly higher XPF levels could be a reason for the observed cisplatin resistance in the HNSCC cells.

In conclusion, our data suggest that XPF might be a useful predictive marker for clinical resistance to cisplatin in HNSCC patients. More detailed studies are now under way to investigate ERCC1 and XPF expression in tissue derived from additional primary and metastatic tumours. This will help to answer the question whether the observed cisplatin resistance in metastatic tumours is due to changes in the NER system.

\section{References}

1. Mashberg A: Head and neck cancer. N Engl J Med 328: 1783-1784, 1993.

2. Vokes EE, Weichselbaum RR, Lippman SM and Hong WK: Head and neck cancer. N Engl J Med 328: 184-194, 1993.

3. Horner MJ RL, Krapcho M, Neyman N, Aminou R, Howlader N, Altekruse SF, Feuer EJ, Huang L, Mariotto A, Miller BA, Lewis DR, Eisner MP, Stinchcomb DG and Edwards BK (eds): SEER Cancer Statistics 1975-2006. National Cancer Institute, Bethesda, MD, 2009.

4. Greenlee RT, Hill-Harmon MB, Murray T and Thun M: Cancer statistics, 2001. CA Cancer J Clin 51: 15-36, 2001.

5. Jones AS, Morar P, Phillips DE, Field JK, Husband D and Helliwell TR: Second primary tumors in patients with head and neck squamous cell carcinoma. Cancer 75: 1343-1353, 1995.

6. Leemans CR, Tiwari R, Nauta JJ, van der Waal I and Snow GB: Recurrence at the primary site in head and neck cancer and the significance of neck lymph node metastases as a prognostic factor. Cancer 73: 187-190, 1994.

7. Bosl GJ and Motzer RJ: Testicular germ-cell cancer. N Engl J Med 337: 242-253, 1997.

8. Walker MC, Parris CN and Masters JR: Differential sensitivities of human testicular and bladder tumor cell lines to chemotherapeutic drugs. J Natl Cancer Inst 79: 213-216, 1987.

9. Masters JRW, Osborne EJ, Walker MC and Parris CN: Hypersensitivity of human testis-tumour cell lines to chemotherapeutic drugs. Int J Cancer 53: 340-346, 1993.

10. Köberle B, Payne J, Grimaldi KA, Hartley JA and Masters JRW: DNA-repair in cisplatin-sensitive and resistant human cell-lines measured in specific genes by quantitative polymerase chainreaction. Biochem Pharmacol 52: 1729-1734, 1996.

11. Köberle B, Grimaldi KA, Sunters A, Hartley JA, Kelland LR and Masters JR: DNA repair capacity and cisplatin sensitivity of human testis tumour cells. Int J Cancer 70: 551-555, 1997.

12. Wood RD: Nucleotide excision repair in mammalian cells. J Biol Chem 272: 23465-23468, 1997.

13. Köberle B, Masters JR, Hartley JA and Wood RD: Defective repair of cisplatin-induced DNA damage caused by reduced XPA protein in testicular germ cell tumours. Curr Biol 9: 273-276, 1999.

14. Welsh C, Day R, McGurk C, Masters JR, Wood RD and Köberle B: Reduced levels of XPA, ERCC1 and XPF DNA repair proteins in testis tumor cell lines. Int J Cancer 110: 352-361, 2004

15. Dabholkar M, Bostick-Bruton F, Weber C, Bohr VA, Egwuagu C and Reed E: ERCC1 and ERCC2 expression in malignant tissues from ovarian cancer patients. J Natl Cancer Inst 84: 1512-1517, 1992.

16. Dabholkar M, Vionnet J, Bostick-Bruton F, Yu JJ and Reed E: Messenger RNA levels of XPAC and ERCC1 in ovarian cancer tissue correlate with response to platinum-based chemotherapy. J Clin Invest 94: 703-708, 1994

17. Metzger R, Leichman CG, Danenberg KD, et al: ERCC1 mRNA levels complement thymidylate synthase mRNA levels in predicting response and survival for gastric cancer patients receiving combination cisplatin and fluorouracil chemotherapy. J Clin Oncol 16: 309-316, 1998. 
18. Lord RV, Brabender J, Gandara D, et al: Low ERCC1 expression correlates with prolonged survival after cisplatin plus gemcitabine chemotherapy in non-small cell lung cancer. Clin Cancer Res 8: 2286-2291, 2002.

19. Pera MF, Blasco LM and Mills J: Cultured stem-cells from human testicular teratomas: the nature of human embryonal carcinoma, and its comparison with two types of yolk-sac carcinoma. Int J Cancer 40: 334-343, 1987.

20. McGurk C, Cummings M, Köberle B, Hartley JA, Oliver RT and Masters JR: Regulation of DNA repair gene expression in human cancer cell lines. J Cell Biochem 97: 1121-1136, 2006.

21. Schubert-Fritschle GGH, Schmidt M, Eckel R, Engel J, Tretter W and Hölzel D: Munich Cancer Registry, Annual Report, 2001

22. Sijbers AM, De Laat WL, Ariza RR, et al: Xeroderma pigmentosum group $\mathrm{F}$ caused by a defect in a structure-specific DNA repair endonuclease. Cell 86: 811-822, 1996.

23. Westerveld A, Hoeijmakers JHJ, van Duin M, et al: Molecular cloning of a human DNA repair gene. Nature 310: 425-429, 1984.

24. Sijbers AM, Vader PCV, Snoek JW, Raams A, Jaspers NGJ and Kleijer WJ: Homozygous r788w point mutation in the xpf gene of a patient with xeroderma-pigmentosum and late-onset neurologic disease. J Invest Dermatol 110: 832-836, 1998.

25. Li Q, Gardner K, Zhang L, Tsang B, Bostick-Bruton F and Reed E: Cisplatin induction of ERCC-1 mRNA expression in A2780/CP70 human ovarian cancer cells. J Biol Chem 273: 23419-23425, 1998

26. Ferry KV, Hamilton TC and Johnson SW: Increased nucleotide excision repair in cisplatin-resistant ovarian cancer cells: role of ERCC1-XPF. Biochem Pharmacol 60: 1305-1313, 2000.

27. Jun HJ, Ahn MJ, Kim HS, et al: ERCC1 expression as a predictive marker of squamous cell carcinoma of the head and neck treated with cisplatin-based concurrent chemotherapy. Br J Cancer 99: 167-172, 2008 .
28. Niedernhofer LJ, Bhagwat $\mathrm{N}$ and Wood RD: ERCC1 and nonsmall-cell lung cancer. N Engl J Med 356: 2538-2539, 2007.

29. Andrews PW, Damjanov I, Simon D, et al: Pluripotent embryonal carcinoma clones derived from the human teratocarcinoma cell line Tera-2. Differentiation in vivo and in vitro. Lab Invest 50: 147-162, 1984

30. Teshima S, Shimosato Y, Hirohashi S, et al: Four new human germ cell tumor cell lines. Lab Invest 59: 328-336, 1988.

31. Bronson DL, Andrews PW, Solter D, Cervenka J, Lange PH and Fraley EE: Cell line derived from a metastasis of a human testicular germ cell tumor. Cancer Res 40: 2500-2506, 1980.

32. Hogan B, Fellous M, Avner P and Jacob F: Isolation of a human teratoma cell line which expresses F9 antigen. Nature 270: 515-518, 1977.

33. Fogh J: Cultivation, characterization, and identification of human tumor cells with emphasis on kidney, testis, and bladder tumors. Natl Cancer Inst Monogr 49: 5-9, 1978.

34. Fogh J, Fogh JM and Orfeo T: One hundred and twenty-seven cultured human tumor cell lines producing tumors in nude mice. J Natl Cancer Inst 59: 221-226, 1977.

35. Rangan SR: A new human cell line (FaDu) from a hypopharyngeal carcinoma. Cancer 29: 117-121, 1972.

36. Gioanni J, Fischel JL, Lambert JC, et al: Two new human tumor cell lines derived from squamous cell carcinomas of the tongue: establishment, characterization and response to cytotoxic treatment. Eur J Cancer Clin Oncol 24: 1445-1455, 1988.

37. Takebayashi S, Hickson A, Ogawa T, et al: Loss of chromosome arm $18 \mathrm{q}$ with tumor progression in head and neck squamous cancer. Genes Chromosomes Cancer 41: 145-154, 2004. 